\title{
Article
}

\section{Mycosphere Essay 19. Cordyceps species parasitizing hymenopteran and hemipteran insects}

\author{
Shrestha $\mathrm{B}^{1}$, Tanaka $\mathrm{E}^{2}$, Hyun $\mathrm{MW}^{3}$, Han $\mathrm{JG}^{3}$, Kim $\mathrm{CS}^{4}$, Jo $\mathrm{JW}^{4}$, Han $\mathrm{SK}^{4}$, Oh \\ $\mathrm{J}^{5,6}$, Sung $\mathrm{JM}^{1}$, Sung GH ${ }^{6,7,8}$ \\ ${ }^{1}$ Mushtech Cordyceps Institute, Cheongil-ro 453 Beon-gil 55-9, Cheongil-myeon, Hoengseong-gun, Gangwon-do \\ 25255, Korea \\ ${ }^{2}$ Ishikawa Prefectural University, Environmental Science 1-308 Suematsu, Nonoichi, Ishikawa 921-8836, Japan \\ ${ }^{3}$ Mushroom Research Division, National Institute of Horticultural and Herbal Science, Rural Development \\ Administration, Eumseong 27709, Korea \\ ${ }^{4}$ Forest Biodiversity Division, Korea National Arboretum, Pocheon 487-820, Korea \\ ${ }^{5}$ College of Pharmacy, Chung-Ang University, Seoul 06974, Korea \\ ${ }^{6}$ Institute for Healthcare and Life Science, International St. Mary's Hospital and College of Medicine, Catholic \\ Kwandong University, Incheon 22711, Korea \\ ${ }^{7}$ Department of Microbiology, College of Medicine, Catholic Kwandong University, Gangneung-si, Gangwon-do \\ 25601, Korea \\ ${ }^{8}$ Institute for Translational and Clinical Research, International St. Mary's Hospital and College of Medicine, Catholic \\ Kwandong University, Incheon 22711, Korea
}

Shrestha B, Tanaka E, Hyun MW, Han JG, Kim CS, Jo JW, Han SK, Oh J, Sung JM, Sung GH 2017 - Mycosphere Essay 19. Cordyceps species parasitizing hymenopteran and hemipteran insects. Mycosphere 8(9), 1424-1442, Doi 10.5943/mycosphere/8/9/8

\begin{abstract}
Hymenoptera and Hemiptera are two major insect orders after Coleoptera and Lepidoptera that are parasitized by Cordyceps species. Among the 52 Cordyceps species parasitizing hymenopterans, the majority (50 species) are recorded on suborder Apocrita (ants, bees, wasps). Ant family Formicidae is the mostly parasitized family followed by Vespidae (wasps). Ophiocordyceps uilateralis, O. sphececephala, O. myrmecophila and Cordyceps australis are some of the cosmopolitan species that parasitize ants and wasps. Among Cordyceps species recorded on hemipterans, the majority (34 species) are recorded on suborder Auchenorrhyncha (cicadas, spittlebugs, froghoppers), followed by six species on suborder sternorhyncha (scale insects) and four species on the suborder Heteroptera (true bugs). Ophiocordyceps nutans is recorded worldwide in Asia, Africa and South America and parasitizes more than 30 species of true bugs. Another worldwide species is Ophiocordyceps sobolifera that parasitizes six cicada species in Asia, Africa and South America. Pentatomidae (true bugs), Cicadidae (cicadas) and Acanthosomatidae (shield bugs) are major host families within Hemiptera. Cordyceps species parasitizing hemipteran insects are phylogenetically very diverse and are currently segregated into Metarhizium, Ophiocordyceps, Polycephalomyces, Purpureocillium and Tolypocladium. Many hymenopterans and hemipterans are important insect pests and have invaded new localities in the world, threatening agriculture and human life. The host information compiled in this review could be informative for their use as potential biocontrol agents of endemic insect pests belonging to Hymenoptera and Hemiptera, including invasive alien species.
\end{abstract}


Key words - biological control - insect hosts - medicinal fungus - Ophiocordyceps

\section{Introduction}

Cordyceps is a hypocrealean entomogenous genus, parasitizing several orders of insects from larva to adult stages (Sung et al. 2007, Shrestha et al. 2014, Araújo \& Hughes 2016). The most expensive biological commodity Chinese caterpillar fungus (Cordyceps sinensis, current name Ophiocordyceps sinensis) that parasitizes hepialid larvae in the alpine grasslands of the Himalayas and the Tibetan Plateau belongs to this broad genus (Sung et al. 2007, Shrestha et al. 2010). Recently, we catalogued Cordyceps species that parasitize coleopteran and lepidopteran insects (Shrestha et al. 2016). Here, we catalogue Cordyceps species parasitizing hymenopterans (ants, bees, wasps) and hemipterans (cicadas, true bugs) that include many agricultural pests and biting/stinging insects. We believe such compiling works help readers get a quick look into the host range of Cordyceps species and their potential as biocontrol agents of insect pests in agricultural lands, forests and recreation parks.

\section{Materials and Methods}

Cordyceps species that parasitize hymenopteran and hemipteran insects are compiled from widely scattered literature, published in the last 170 years. The major subgroups of the two insect orders Hymenoptera and Hemiptera are briefly introduced, followed by Cordyceps species that parasitize them. The distributions of Cordyceps species are indicated here in the continental scale, though their records are mostly concentrated in a few countries within each continent. The hosts are also analyzed for life stages at which they are parasitized by Cordyceps species such as adult, nymph, pupa or larva.

Nomenclature of many Cordyceps species have recently changed after their transfer to older as well as newly established genera such as Metarhizium (Kepler et al. 2014), Ophiocordyceps (Sung et al. 2007), Polycephalomyces (Kepler et al. 2013), Purpureocillium (Ban et al. 2015), Tolypocladium (Quandt et al 2014) and others (Spatafora et al. 2015). We have followed the current names of Cordyceps species in this review. Despite segregation of Cordyceps into several genera, we have frequently used the generic name Cordyceps in a wide sense throughout the text for the reason of simplicity. We have also included newly described species in Ophiocordyceps as far as they fit into the conventional sense of Cordyceps (Shrestha et al 2014).

\section{Order Hymenoptera}

Hymenoptera is the third-largest insect order, after Coleoptera and Lepidoptera. The common members of this group are ants, bees, wasps and sawflies. Many of them are economically important pollinators and agricultural pests. The members of Hymenoptera are classified into two suborders, Apocrita and Symphyta. Both suborders are parasitized by Cordyceps species (Tables 1, 2).

\section{Suborder Apocrita}

Its members are ants, bees and wasps. Stinging wasps and ants are mostly carnivorous whereas bees feed on pollen and nectar. Cordyceps species parasitize three superfamilies of this suborder.

\section{Superfamily Apoidea}

Its members are wasps and bees. Some of them are notable pests. Three families in this superfamily are known to be parasitized by Ophiocordyceps species.

\section{Family Apidae}

It is a family of bees. They are widespread, mainly in Neotropical and Oriental regions. Ophiocordyceps oxycephala parasitizes Bombus equestris in Asia (Kobayasi 1941) (Table 1). Similarly, O. sphecocephala parasitizes a species of honey bee (Apis) in Africa (Moureau 1949) 
Table 1 Cordyceps species parasitizing order Hymenoptera.

\begin{tabular}{|c|c|c|c|c|}
\hline Cordyceps species & Host family & Host genus/species & Host stage & Distribution \\
\hline Cordyceps coronilla & Tenthredinidae & - & adult & South America \\
\hline C. langloisii & Vespidae & Vespa muraria & larva & North America \\
\hline C. odyneri & Vespidae & Odynerus sp. & larva & Europe \\
\hline C. phymatospora & Ichneumonidae & - & adult & Asia \\
\hline Ophiocordyceps ditmarii & $\begin{array}{l}\text { Ichneumonidae } \\
\text { Siricidae } \\
\text { Vespidae }\end{array}$ & $\begin{array}{l}\text { Amblyteles armatorius } \\
\text { Sirex juvencus } \\
\text { Dolichovespula sylvestris, Polistes gallicus, Vespa crabro, } \\
\text { Vespula germanica, Vespula vulgaris }\end{array}$ & adult & Europe \\
\hline O. elongatistromata & Vespidae & Vespa sp. & adult & Asia \\
\hline O. gentilis & Sphecidae & - & adult & Asia \\
\hline O. humbertii & $\begin{array}{l}\text { Vespidae } \\
\text { Mutillidae } \\
\text { Ichneumonidae }\end{array}$ & $\begin{array}{l}\text { Vespa cincta } \\
\text { Mutilla } \mathrm{sp} .\end{array}$ & adult & $\begin{array}{l}\text { Africa, South } \\
\text { America }\end{array}$ \\
\hline O. lachnopoda & - & - & adult & Asia \\
\hline O. oxycephala & $\begin{array}{l}\text { Apidae } \\
\text { Vespidae }\end{array}$ & $\begin{array}{l}\text { Bombus equestris } \\
\text { Vespa velutina }\end{array}$ & adult & Asia \\
\hline O. smithii & Vespidae & - & adult & North America \\
\hline O. sphecocephala & $\begin{array}{l}\text { Apidae } \\
\text { Crabronidae } \\
\text { Sphecidae } \\
\text { Vespidae }\end{array}$ & $\begin{array}{l}\text { Apis } \mathrm{sp} ., \text { Xylocopa } \mathrm{sp} . \\
\text { Tachytes chrysopiga } \\
\text { Pelopeus sp. } \\
\text { Belonogaster sp., Gymnopolybia sp., Mischocyttarus cubensis, } \\
\text { Parapolybia orientalis, Polistes crinitus americanus, } P . \text { clavaria, } P \text {. } \\
\text { hebraeus, P. lineatus, Polybia fasciata, Vespa auraria, } V . \\
\text { mandarinia, Vespula vulgaris }\end{array}$ & adult & $\begin{array}{l}\text { Africa, Asia, } \\
\text { Europe, South } \\
\text { America }\end{array}$ \\
\hline
\end{tabular}

and a species of carpenter bee (Xylocopa) in South America (Hennings 1902a) (Table 1).

\section{Family Crabronidae}

Its members are wasps, generally solitary and predatory, preying on a wide range of insects and spiders. Ophiocordyceps sphecocephala parasitizes Tachytes chrysopiga in South America (van Vooren \& Audibert 2005) (Table 1). 


\section{Family Sphecidae}

It is a cosmopolitan family of parasitoid wasps that prey on larvae of insects and spiders. Ophiocordyceps sphecocephala parasitizes a species of Pelopeus in Africa (Moureau 1949) (Table 1). Similarly, O. gentilis parasitizes a species of wasp of this family in Asia (Cesati 1879).

\section{Superfamily Ichneumonoidea}

Wasps belonging to family Ichneumonidae are reported to be parasitized by three Cordyceps species. One of them is Ophiocordyceps ditmarii that parasitizes Amblyteles armatorius in Europe (Mornand et al. 2012) (Table 1). Besides family Ichneumonidae, O. ditmarii also parasitizes members of Vespidae (suborder Apocrita) and Siricidae (suborder Symphyta). Apart from Hymenoptera, O. ditmarii is also recorded on Diptera (Mornand et al. 2012). Other two species parasitizing family Ichneumonidae are O. humbertii in South America (Hennings 1902b) and C. phymatospora in Asia (Li et al. 2002) (Table 1).

Table 2 Cordyceps species parasitizing family Formicidae of order Hymenoptera.

\begin{tabular}{lll}
\hline Cordyceps species & Host species & Distribution \\
\hline Cordyceps australis & Bothroponera pachyderma, Megaponera foetens, Pachycondyla crassinoda, Pac. & Africa, South \\
America & Afriata, Paltothyreus tarsatus, Paraponera clavata, Phrynoponera sp. \\
C. carnata & Paltothyreus tarsatus & South America \\
C. doiana & Paraponera clavata & Asia \\
C. morakotii & Odontomachus sp. & Asia \\
C. myrmecogena & - & South America \\
C. pilifera & - & South America \\
Ophiocordyceps camponoti-atricipis & Camponotus atriceps & South America \\
O. camponoti-balzani & Camponotus balzani & South America \\
O. camponoti-bispinosi & Camponotus bispinosus & South America \\
O. camponoti-indiani & Camponotus indianus & Asia \\
O. camponoti-leonardi & Camponotus leonardi & South America \\
O. camponoti-melanotici & Camponotus melanoticus & South America \\
O. camponoti-novogranadensis & Camponotus novogranadensis & South America \\
O. camponoti-rufipedis & Camponotus rufipes & Asia \\
O. camponoti-saundersi & Camponotus saundersi & South America \\
O. cucumispora & Cephalotes atratus & South America
\end{tabular}


O. evansii

O. formicarum

O. halabalaensis

O. irangiensis

O. japonensis

O. kniphofioides

O. kniphofioides var. dolichoderi

O. kniphofioides var. monacidis

O. lloydii

O. lloydii var. binata

O. myrmecophila

O. polyrhachis-furcata

O. ponerinarum

O. proliferans

O. pseudolloydii

O. pulvinata

O. rami

O. ridleyi

O. septa

O. sessilis

O. subunilateralis

O. unilaterialis
Pachycondyla impressa

Camponotus obscuripes, $C$. japonicus

Camponotus gigas

Camponotus sp., Polyrhachis sp.

Camponotus sp.

Cephalotes atratus

Dolichoderus attelaboides

Monacis bispinosa

Camponotus atriceps

Camponotus sp.

Camponotus piceus, Dinoponera grandis, Formica fusca, F. polyctena, F. pratensis, F. Asia, Europe, North rufa, F. sanguinea, Myrmica laevinodis, M. rufa, Paltothyreus tarsatus, Polyrhachis sp. and South America

Polyrhachis furcata

Paraponera clavata, Dinoponera longipes

Dinoponera grandis, Megaponera sp.

Dolichoderus bituberculatus

Camponotus obscuripes

Camponotus sp.

Camponotus gigas

Camponotus sp.

Camponotus obscuripes

Formica sp.

Atta cephalotes, Camponotus atriceps, C. brutus, C. americanus, C. leonardi, C.

ligniperdus, $C$. pennsylvanicus, $C$. saundersi, $C$. sericeiventris, $C$. vividus, Echinopla melanarctos, Megaponera foetens, Phasmomyrmex aberrans, Ph. buchneri, Ph.

paradoxus, Polyrhachis armata, $P$. decemdentata, $P$. fissa, $P$. furcata, $P$. hippomanes,

$P$. laboriosa, P. latharis, $P$. latispina, $P$. militaris, $P$. monista, $P$. proxima, $P$. revoili, $P$.

rufofemorata, $P$. sulcata

Polyrhachis lamellidens
South America

Asia

Asia

Africa, Asia

Asia

South America

South America

South America

South America

South America

Asia

South America

South America

Asia

Asia

Asia

Asia

Asia

Asia

South America

Asia, North and

South America
Asia

O. unilateralis var. clavata

\section{Superfamily Vespoidea}

It includes common members such as ants and paper-nesting wasps. They are mostly tropical in distribution. Following three families are 
parasitized by Cordyceps species.

\section{Family Formicidae}

The common examples are ants. Out of 52 Cordyceps species that are known to parasitize hymenopterans, 40 species parasitize ants belonging to five subfamilies (Table 2).

Subfamily Dolichoderinae. Ophiocordyceps cucumispora var. dolichoderi and $O$. kniphofioides var. dolichoderi are recorded on Dolichoderus attelaboides, and O. kniphofioides var. monacidis on Monacis bispinosa in South America (Evans \& Samson 1982) (Table 2). Similarly, O. pseudolloydii is recorded on Dolichoderus bituberculatus in Asia (Tzean et al. 1997) (Table 2).

Subfamily Formicinae. Five genera in this subfamily are known to be parasitized by Ophiocordyceps species. Among them, Camponotus is most commonly parasitized, followed by Polyrhachis, Formica, Phasmomyrmex and Echinopla.

Camponotus is a diverse ant genus. Twenty two Ophiocordyceps species parasitize Camponotus ants (Table 2). Among them, O. unilateralis parasitizes multiple Camponotus species, such as C. atriceps (Fawcett 1886) and C. sericeiventris (Evans \& Samson 1984) in South America, C. brutus and C. vividus in Africa (Evans 1974), C. pennsylvanicus (Bequaert 1922) and C. americanus (Mains 1940) in North America, C. leonardi (Pontoppidan et al. 2009) and $C$. saundersi (Luangsa-Ard et al. 2011) in Asia, and C. ligniperdus (Bequaert 1922) in Europe and North America (Table 2). Similarly, O. formicarum parasitizes Camponotus obscuripes (Kobayasi 1939b) and C. japonicus (Kawamura 1955) in Asia (Table 2).

However, most other Ophiocordyceps species are recorded on distinct Camponotus ants (Table 2). For example, in South America, O. camponoti-balzani is recorded on C. balzani (Evans et al. 2011), and $O$. camponoti-bispinosi and $O$. camponoti-indiani on $C$. bispinosus and $C$. indianus, respectively (Araújo et al. 2015). Other species recorded on Camponotus ants in South America are $O$. camponoti-melanotici on $C$. melanoticus, $O$. camponoti-novogranadensis on $C$. novogranadensis and $O$. camponoti-rufipedis on $C$. rufipes (Evans et al. 2011). Similarly, $O$. camponoti-leonardi is recorded on C. leonardi and O. camponoti-saundersi on C. saundersi in Asia (Kobmoo et al. 2012) (Table 2). Ophiocordyceps myrmecophila is recorded on Camponotus piceus in Europe (Kautman \& Kautmanová 2009).

In other cases, more than one species of Ophiocordyceps parasitize the same ant species (Table 2). For example, O. camponoti-atricipis (Araújo et al. 2015, Sobczak et al. 2017), and $O$. lloydii and O. unilateralis (Fawcett 1886) are recorded on Camponotus atriceps in South America. Similarly, O. formicarum (Kobayasi 1939b), O. pulvinata (Kepler et al. 2011) and O. sessilis (Kaitsu et al. 2013) are recorded on C. obscuripes in Asia. Ophiocordyceps sessilis is found hyperparasitizing O. pulvinata (Kaitsu et al. 2013). Ophiocordyceps ridleyi (Bequaert 1922) and $O$. halabalaensis (Luangsa-Ard et al. 2011) are recorded on C. gigas in Asia. Ophiocordyceps lloydii var. binata (Evans \& Samson 1984) in South America, O. irangiensis (Moureau 1961) in Africa, and O. japonensis (Bequaert 1922), and O. rami and O. septa (Kobmoo et al. 2015) in Asia are other species that parasitize Camponotus species.

Polyrhachis is another diverse ant genus that is parasitized by several Ophiocordyceps species (Table 2). Among them, Ophiocordyceps unilateralis parasitizes Polyrhachis decemdentata, P. fissa, P. laboriosa, P. latharis, P. latispina, P. militaris, P. monista, P. revoili and $P$. sulcata in Africa (Evans 1974), and P. armata, $P$. furcata, $P$. hippomanes, $P$. proxima and $P$. rufofemorata in Asia (Fawcett 1886, Luangsa-Ard et al. 2011). Ophiocordyceps unilateralis var. clavata parasitizes $P$. lamellidens (Kobayasi 1939b) and $O$. polyrhachis-furcata parasitizes $P$. furcata (Kobmoo et al. 2012) in Asia. Ophiocordyceps irangiensis also parasitizes a species of Polyrhachis (Tzean et al. 1997), including an undetermined species of this subfamily (Hywel-Jones 1996). Another species recorded on Polyrhachis is O. myrmecophila (Tzean et al. 1997) in Asia. Earlier, Teng (1934), Kobayasi \& Shimizu (1976) and Chen (1978) recorded O. myrmecophila in Asia, including New Guinea, on formicid ants. Ophiocordyceps unilateralis additionally parasitizes Echinopla melanarctos in Asia (Fawcett 1886), and Phasmomyrmex aberrans, Ph. buchneri and Ph. paradoxus in Africa (Evans 1974) (Table 2). 
Table 3 Cordyceps species parasitizing suborder Auchenorrhyncha of order Hemiptera.

\begin{tabular}{|c|c|c|c|c|}
\hline Cordyceps species & Host family & Host Genus/species & Host stage & Distribution \\
\hline$\overline{\text { Ophiocordyceps tricentri }}$ & Aphrophoridae & $\begin{array}{l}\text { Aphrophora flavomaculata, A.intermedia, A. rugosa, } \\
\text { Peuceptyelus medius }\end{array}$ & adult & Asia \\
\hline Cordyceps atewensis & Cercopidae & - & adult & Africa \\
\hline C. hesleri & Cicadidae & - & nymph & North America \\
\hline C. imagamiana & Cicadidae & - & nymph & Asia \\
\hline C. kobayasii & Cicadidae & Meimuna opalifera & nymph & Asia \\
\hline C. minuta & Cicadidae & Oncotympana maculaticollis & adult & Asia \\
\hline C. pluricapitata & Cicadidae & - & nymph & Asia \\
\hline C. polycephala & Cicadidae & Euteropnosia iwasakii & nymph & Asia \\
\hline C. zhejiangensis & Cicadidae & Cicada flammata & nymph & Asia \\
\hline Metarhizium guniujiangense & Cicadidae & - & nymph & Asia \\
\hline M. owariense & Cicadidae & Platypleura kaempferi & nymph & Asia \\
\hline M. owariense f. viridescens & Cicadidae & - & nymph & Asia \\
\hline Ophiocordyceps araracuarensis & Cicadidae & - & adult & South America \\
\hline O. cicadicola & Cicadidae & - & adult & Asia \\
\hline O. evdogeorgiae & Cicadidae & - & adult & Russia \\
\hline O. heteropoda & Cicadidae & $\begin{array}{l}\text { Tibicen bihamatus, T. japonicus, Graptopsaltria } \\
\text { nigrofuscata }\end{array}$ & nymph & Asia \\
\hline O. heteropoda var. langyashanensis & Cicadidae & - & nymph & Asia \\
\hline O. longissima & Cicadidae & Tanna japonensis & nymph & Asia \\
\hline O. pseudolongissima & Cicadidae & - & nymph & Asia \\
\hline O. sobolifera & Cicadidae & $\begin{array}{l}\text { Graptopsaltria nigrofuscata, Meimuna opalifera, } \\
\text { Platypleura kaempferi, Proalba chariclo, P. hilaris, Rihana } \\
\text { mesochlora }\end{array}$ & nymph & $\begin{array}{l}\text { Asia, Africa, } \\
\text { South America }\end{array}$ \\
\hline O. takaoensis & Cicadidae & Tanna japonensis & nymph & Asia \\
\hline O. wuyishanensis & Cicadidae & - & nymph & Asia \\
\hline O. yakusimensis & Cicadidae & Meimuna tsuchidai & nymph & Asia \\
\hline Polycephalomyces kanzashianus & Cicadidae & - & nymph & Asia \\
\hline
\end{tabular}




\begin{tabular}{|c|c|c|c|c|}
\hline P. nipponicus & Cicadidae & Graptopsaltria nigrofuscata & nymph & Asia \\
\hline P. prolificus & Cicadidae & Tanna japonensis & nymph & Asia \\
\hline P. prolificus $f$. terminalis & Cicadidae & Tanna japonensis & nymph & Asia \\
\hline P. ramosipulvinatus & Cicadidae & - & nymph & Asia \\
\hline Purpureocillium takamizusanense & Cicadidae & Oncotympana maculaticollis & adult & Asia \\
\hline Tolypocladium paradoxum & Cicadidae & Graptopsaltria nigrofuscata, Platypleura kaempferi & nymph & Asia \\
\hline T. toriharamontanum & Cicadidae & Tibicen bihamatus & nymph & Asia \\
\hline T. inegoense & Cicadidae & Oncotympana maculaticollis & nymph & Asia \\
\hline Ophiocordyceps lutea & $\begin{array}{l}\text { Flatidae } \\
\text { Fulgoridae }\end{array}$ & - & adult & Africa \\
\hline O. fulgoromorphila & Fulgoridae & - & adult & South America \\
\hline
\end{tabular}

Among Formica species, Ophiocordyceps myrmecophila was originally recorded on $F$. fusca in Europe (Nylander 1869) and later on $F$. polyctena, F. pratensis, F. rufa and F. sanguinea (Nylander 1869, Kautman \& Kautmanová 2009, Mornand et al. 2012) (Table 2). In South America, Ophiocordyceps subunilateralis is recorded on a species of Formica (Saccardo 1905).

Subfamily Myrmicinae. It is a cosmopolitan subfamily that is parasitized by several Ophiocordyceps species (Table 2). Among them, $O$. unilateralis parasitizes Atta cephalotes in South America (Tulasne \& Tulasne 1865). Similarly, O. kniphofioides and O. cucumispora parasitize Cephalotes atratus (Evans \& Samson 1982) in South America, and O. myrmecophila parasitizes Myrmica laevinodis (Kautman \& Kautmanová 2009) and M. rufa (Fawcett 1886) in Europe and North America.

Subfamily Paraponerinae. Cordyceps australis (Sanjuán et al. 2001), C. doiana (Kobayasi 1981) and Ophiocordyceps ponerinarum (Sanjuán et al. 2015) are found to parasitize Paraponera clavata in South America (Table 2).

Subfamily Ponerinae. Several Cordyceps species are known to parasitize ponerine ants (Table 2). Among them, Cordyceps australis parasitizes Bothroponera pachyderma (Evans 1974), Paltothyreus tarsatus (Bequaert 1922) and Phrynoponera sp. (Evans 1982) in Africa, and Pachycondyla crassinoda (Evans 2001), Pac. striata (Spegazzini 1881) and Megaponera foetens (Petch 1932) in South America. Similarly, Ophiocordyceps myrmecophila parasitizes Dinoponera grandis in South America (Hennings 1904), and Paltothyreus tarsatus in Africa (Bequaert 1922). Ophiocordyceps proliferans is another species recorded on Dinoponera grandis (Hennings 1904) and a Megaponera species (Kobayasi 1941) in South America.

Cordyceps carnata (Evans 2001) is also recorded on Paltothyreus tarsatus in Africa. Other species recorded on this subfamily are O. evansii on Pachycondyla impressa and O. ponerinarum on Dinoponera longipes (Sanjuán et al. 2015) and O. unilateralis on Megaponera foetens (Petch 1934) in South America. Exceptionally, Cordyceps morakotii is recently recorded on pupa of a species of Odontomachus (Tasanathai et al. 2016) (Table 2). All other Cordyceps species are recorded on adult ants. Besides them, C. myrmecogena in Asia (Kobayasi \& Shimizu 1978) and C. pilifera in South America (Kobayasi 1981) are recorded on adult formicid ants. 


\section{Family Mutillidae}

It is a group of wasps, with predominantly tropical distributions. Ophiocordyceps humbertii parasitizes a species of Mutilla in South America (Spegazzini 1889) (Table 1).

\section{Family Vespidae}

Its members include solitary as well as eusocial wasps, with mainly tropical distributions. Some stinging wasps in this family are important agricultural pests. Several Cordyceps species are known to parasitize three subfamilies of this family.

Subfamily Eumeninae. The members are mostly solitary and few subsocial wasps. Cordyceps odyneri parasitizes larvae of a species of Odynerus in Europe (Saccardo 1891) (Table 1).

Subfamily Polistinae. All the members are eusocial wasps. Ophiocordyceps sphecocephala parasitizes eight species of this subfamily. They are Belonogaster sp. (Moureau 1949) in Africa, Gymnopolybia sp. (Petch 1934), Mischocyttarus cubensis (Wolcott 1948), Polistes crinitus americanus (Kobayasi 1939b), P. clavaria (Tulasne \& Tulasne 1865), P. lineatus (Johnston 1918) and Polybia fasciata (Kobayasi 1939b) in South America, and Parapolybia orientalis (Kawamura 1955) and Polistes hebraeus (Kobayasi 1939b) in Asia (Table 1). Similarly, O. ditmarii parasitizes Polistes gallicus in Europe (Cejp 1956) (Table 1).

Subfamily Vespinae. All the members are eusocial wasps. Ophiocordyceps sphecocephala parasitizes Vespa auraria (Kobayasi 1939b) and V. mandarinia (Kawamura 1955) in Asia, and Vespula vulgaris (Kautman \& Kautmanová 2009) in Europe (Table 1). Similarly, O. ditmarii parasitizes four species in Europe, Dolichovespula sylvestris, Vespula germanica and V. vulgaris (Cejp 1956), and Vespa crabro (Saccardo 1883) (Table 1). Ophiocordyceps humbertii is recorded on Vespa cincta (de Saussure 1853) in Africa and O. oxycephala on Vespa velutina (Penzig \& Saccardo 1897) in Asia. Similarly, Ophiocordyceps elongatistromata is recorded on a species of Vespa in Asia (Kobayasi \& Shimizu 1983). Cordyceps langloisii is recorded on a larva of Vespa muraria in North America (Saccardo 1895), the only larval stage among hymenopterans to be parasitized by Cordyceps species. Apart from them, $O$. smithii is recorded on a species of Vespidae in North America (Mains 1939). Similarly, O.lachnopoda is recorded on an adult wasp in Asia (Penzig \& Saccardo 1897) (Table 1).

\section{Suborder Symphyta}

It is a small group that consists of sawflies, horntails, parasitic wood wasps, leaf feeders etc. Few of them cause economic damage to forest and cultivated plants. Two Cordyceps species are known to parasitize superfamilies Tenthredinoidea and Siricoidea in this suborder.

\section{Superfamily Tenthredinoidea}

Its members are called leaf feeders and some of them are important agricultural pests. Cordyceps coronilla parasitizes a species of family Tenthredinidae in South America (Saccardo \& Trotter 1913) (Table 1).

\section{Superfamily Siricoidea}

Its members are xylophagous sawflies, horntails and wood wasps, some of which are important agricultural pests. Ophiocordyceps ditmarii parasitizes Sirex juvencus (family Siricidae) in Europe (Mornand et al. 2012) (Table 1).

\section{Order Hemiptera}

Hemiptera is the fifth largest order of insects after Coleoptera, Lepidoptera, Hymenoptera and Diptera, and one of the major host orders of entomopathogenic fungi (Araújo \& Hughes 2016). Commonly known members of this order are cicadas, aphids, true bugs, planthoppers, leafhoppers, scale insects, whiteflies etc. They are mostly phytophagous and are important pests in agriculture. Hemipterans are classified into four suborders Auchenorrhyncha, Coleorrhyncha, Heteroptera and 
Sternorrhyncha, all of which except Coleorrhyncha are known to be parasitized by Cordyceps species (Tables 3-5).

Table 4 Ophiocordyceps species parasitizing suborder Heteroptera of order Hemiptera.

\begin{tabular}{|c|c|c|c|c|}
\hline $\begin{array}{l}\text { Ophiocordyceps } \\
\text { species }\end{array}$ & Host family & Host Genus/species & $\begin{array}{l}\text { Host } \\
\text { stage }\end{array}$ & Distribution \\
\hline O. nigra & Reduviidae & - & nymph & Africa \\
\hline \multirow[t]{9}{*}{ O. nutans } & Acanthosomatidae & $\begin{array}{l}\text { Acanthosoma denticauda, } \text { A. } \\
\text { forficula, } \text { A. haemorrhoidale } \\
\text { angulata, A. labiduroides, } \\
\text { Elasmucha putoni, Sastragala } \\
\text { esakii, S. scutellata }\end{array}$ & Adult & $\begin{array}{l}\text { Africa, Asia, } \\
\text { South } \\
\text { America, } \\
\text { New Guinea }\end{array}$ \\
\hline & Coreidae & $\begin{array}{l}\text { Molipteryx fuliginosa, } \\
\text { Homoeocerus dilatatus, Ho. } \\
\text { unipunctatus, Hygia lativentris, } \\
\text { Hy. opaca }\end{array}$ & & \\
\hline & Dinidoridae & $\begin{array}{l}\text { Megymenum gracilicorne, } M \text {. } \\
\text { tauriforme }\end{array}$ & & \\
\hline & Pentatomidae & $\begin{array}{l}\text { Caura pugillator, Dinorhynchus } \\
\text { dybowskyi, Erthesina fullo, } \\
\text { Gonopsis affinis, Halyomorpha } \\
\text { halys, H. picus, Homalogonia } \\
\text { obtusa, Lelia decempunctata, } \\
\text { Nezara antennata, Pentatoma } \\
\text { japonica, P. rufipes, Picromerus } \\
\text { lewisi, Plautia stali, Tropicoris } \\
\text { japonicus }\end{array}$ & & \\
\hline & Plataspididae & Coptosoma punctissimum & & \\
\hline & Pyrrhocoridae & Callibaphus longirostris & & \\
\hline & Reduviidae & - & & \\
\hline & Tessaratomidae & Oncomeris sp. & & \\
\hline & Urostylididae & Urostylis annulicornis & & \\
\hline O. pentatomae & Pentatomidae & $\begin{array}{l}\text { Pentatoma semiannulata, Lelia } \\
\text { decempunctata }\end{array}$ & adult & Asia, Russia \\
\hline O. sichuanensis & Pentatomidae & - & adult & Asia \\
\hline
\end{tabular}

\section{Suborder Auchenorrhyncha}

Common members of this suborder are cicadas, leafhoppers, treehoppers, planthoppers, spittlebugs, froghopper etc. that are distributed worldwide. All the members are plant-feeders. Two infraorders in this suborder are known to be parasitized by 34 Cordyceps species.

\section{Infraorder Cicadomorpha}

The common members are cicadas, leafhoppers, treehoppers, froghoppers and spittlebugs. They are distributed worldwide, but mainly in the tropical and subtropical zones. Two superfamilies are parasitized by Cordyceps species.

\section{Superfamily Cercopoidea}

Its common members are spittlebugs and froghoppers. Two families are known to be parasitized by Cordyceps species. 


\section{Family Aphrophoridae}

The members are spittlebugs and are mainly distributed in the Palaeartic and Oriental regions. They feed on xylem fluid and cause heavy economic losses to grass crops including rice, sugarcane, corn and pasture grasses. Adults of Aphrophora flavomaculata, A. intermedia, A. rugosa and Peuceptyelus medius are parasitized by Ophiocordyceps tricentri in Asia (Kobayasi 1941, Kawamura 1955) (Table 3).

\section{Family Cercopidae}

The members are called froghoppers. Cordyceps atewensis parasitizes adults of this family in Africa (Samson et al. 1982) (Table 3).

\section{Superfamily Cicadoidea}

Common members of this superfamily are cicadas. They are large, xylem-feeding insects on tree roots with long underground juvenile stages and brief aboveground adult lives. In summer, male cicadas produce calling songs for pair formation and courtship. Cicadas (family Cicadidae) have long been known to be parasitized by Cordyceps species in the Orient as well as the West (Kobayasi \& Shimizu 1963). Many of them currently belong to Metarhizium, Ophiocordyceps, Polycephalomyces, Purpureocillium and Tolypocladium (Table 3). Altogether, 30 species (eleven Ophiocordyceps species, seven Cordyceps species, five Polycephalomyces species, three Metarhizium species, three Tolypocladium species and one species of Purpureocillium) are known to parasitize cicada species, mostly in Asia. Species recorded specifically outside of Asia are Cordyceps hesleri in North America (Mains 1939) and Ophiocordyceps araracuarensis in South America (Sanjuán et al. 2015).

Among Cordyceps species parasitizing cicadas, Ophiocordyceps sobolifera parasitizes several species such as Graptopsaltria nigrofuscata, Meimuna opalifera, Platypleura kaempferi, Proalba chariclo, P. hilaris and Rihana mesochlora distributed in South America, Africa and Asia (Kobayasi 1941, Kinjo et al. 2004) (Table 3). Ophiocordyceps heteropoda and Tolypocladium paradoxum are other species parasitizing multiple cicada species in Asia (Kobayasi 1939a). Ophiocordyceps heteropoda parasitizes Graptopsaltria nigrofuscata, Tibicen bihamatus and $T$. japonicas and Tolypocladium paradoxum parasitizes Graptopsaltria nigrofuscata and Platypleura kaempferi (Table 3).

Other Cordyceps species recorded on cicadas are Cordyceps zhejiangensis on Cicada flammata (Shing 1975), C. kobayasii on Meimuna opalifera (Kobayasi 1949), C. polycephala on Euteropnosia iwasakii (Kobayasi \& Shimizu 1983), Metarhizium owariense on Platypleura kaempferi (Kobayasi 1939a), O. yakusimensis on Meimuna tsuchidai (Kobayasi \& Shimizu 1963), Po. nipponicus on Graptopsaltria nigrofuscata (Kobayasi 1939a), and T. toriharamontanum on Tibicen bihamatus (Kobayasi \& Shimizu 1963) (Table 3). Similarly, O. longissima, Po. prolificus and Po. prolificus f. terminalis (Kobayasi \& Shimizu 1963) and O. takaoensis (Kobayasi 1939a) are recorded on Tanna japonensis. Cordyceps minuta, Pu. takamizusanense and T. inegoense are other species recorded on Oncotympana maculaticollis (Kobayasi \& Shimizu 1963) (Table 3).

Few other Cordyceps species recorded on undetermined cicada species are Cordyceps hesleri (Mains 1939), C. imagamiana (Kobayasi \& Shimizu 1983), C. pluricapitata (Kobayasi \& Shimizu 1982a), M. guniujiangense (Li et al. 2010), M. owariense f. viridescens (Uchiyama \& Udagawa 2002), O. araracuarensis (Sanjuán et al. 2015), O. cicadicola (Teng 1935), O. evdogeorgiae (Koval 1961), O. heteropoda var. langyashanensis (Li et al. 2006), $O$. pseudolongissima (Kobayasi \& Shimizu 1982b), O. wuyishanensis (Liang et al. 2002), Po. kanzashianus (Kobayasi \& Shimizu 1982a) and Po. ramosipulvinatus (Kobayasi \& Shimizu 1983) (Table 3).

Some cicadas are parasitized by multiple Cordyceps species (Table 3). For instance, Tanna japonensis is parasitized by O. longissima, O. takaoensis, Po. prolificus and Po. prolificus f. terminalis (Kobayasi 1939a, Kobayasi \& Shimizu 1963), and Graptopsaltria nigrofuscata by $O$. heteropoda, O. sobolifera, Po. nipponicus and T. paradoxum (Kobayasi 1939a, Kinjo et al. 2004). 
Similarly, Oncotympana maculaticollis is parasitized by C. minuta, Pu. takamizusanense and T. inegoense (Kobayasi \& Shimizu 1963), Platypleura kaempferi by M. owariense, O. sobolifera and T. paradoxum (Kobayasi 1939a, Kobayasi 1941), Meimuna opalifera by C. kobayasii and $O$. sobolifera (Kobayasi 1949, Kinjo et al. 2004), and Tibicen bihamatus by O. heteropoda and T. toriharamontanum (Kobayasi 1939a, Kobayasi \& Shimizu 1963). Among Cordyceps species parasitizing cicadas, C. minuta, O. araracuarensis, O. cicadicola, O. evdogeorgiae and Pu. takamizusanense parasitize adults, the remainings parasitize nymphs (Table 3).

Table 5 Cordyceps species parasitizing suborder Sternorrhyncha of order Hemiptera

\begin{tabular}{lllll}
\hline Cordyceps species & $\begin{array}{l}\text { Host superfamily/ } \\
\text { family }\end{array}$ & Host Genus/species & $\begin{array}{l}\text { Host } \\
\text { stage }\end{array}$ & Distribution \\
\hline Cordyceps confragosa & Coccidae & - & adult & South America \\
C. yahagiana & Coccidae & - & adult & Asia \\
Ophiocordyceps coccidiicola & Coccidae & Ceroplastes sp. & adult & Asia \\
O. clavulata & Coccidae & Eulecanium coryli, & adult & Europe, North \\
& & Lecanium persicae, & & America \\
& & Coccus sp. & & \\
Cordyceps piperis & Coccoidea & - & adult & South America \\
C. novae-zelandiae & Coelostomidiidae & Coelostomidia sp. & adult & New Zealand \\
\hline
\end{tabular}

\section{Infraorder Fulgoromorpha}

Its common members are planthoppers and are mainly distributed in the tropical and subtropical zones. Two families (Flatidae and Fulgoridae) in superfamily Fulgoroidea are parasitized by Cordyceps species in Africa and South America. Ophiocordyceps lutea parasitizes adults of Flatidae and Fulgoridae in Africa (Moureau 1949) while O. fulgoromorphila parasitizes adults of Fulgoridae in South America (Sanjuán et al. 2015) (Table 3).

\section{Suborder Heteroptera}

The members of Heteroptera are commonly known as true bugs. Two infraorders are parasitized by Ophiocordyceps species (Table 4).

\section{Infraorder Cimicomorpha}

Nymphs and adults of family Reduviidae (superfamily Reduvioidea) of this infraorder are parasitized by Ophiocordyceps nigra (Samson et al. 1982) and O. nutans (Moureau 1949) in Africa (Table 4).

\section{Infraorder Pentatomomorpha}

It is a large group of seed-eating stink bugs, flat bugs, seed bugs etc. Following superfamilies are parasitized by Ophiocordyceps species.

\section{Superfamily Coreoidea}

Ophiocordyceps nutans parasitizes several members of family Coreidae of this superfamily in Asia. They are Molipteryx fuliginosa, Homoeocerus unipunctatus and Hygia opaca (Esaki 1929), Ho. dilatatus (Kawamura 1955) and Hy. lativentris (Sasaki et al. 2012) (Table 4).

\section{Superfamily Pentatomoidea}

Its members are shield bugs, chust bugs or stink bugs and many of them are pests of economically important crops such as peach, apple, filbert nut, pear, wheat, grapes, small fruit, field corn, soybean, sorghum, sweet corn, tomato, pepper, okra and eggplant. Six families in this superfamily are parasitized by Ophiocordyceps species. 


\section{Family Acanthosomatidae}

Members of this family are known as shield bugs and mostly feed on developing fruits of conifers and flowering plants. Acanthosoma denticauda, A. forficula, A. haemorrhoidale angulata, A. labiduroides, Elasmucha putoni, Sastragala esakii and S. scutellata are parasitized by Ophiocordyceps nutans in Asia (Esaki 1929, Sasaki et al. 2012) (Table 4).

\section{Family Dinidoridae}

Its members are large, colored bugs and are phytophagous. Megymenum gracilicorne and M. tauriforme are parasitized by O. nutans in Asia (Esaki 1929, Kawamura 1955) (Table 4).

\section{Family Pentatomidae}

It is a cosmopolitan family of stink bugs. They are predacious and are important biocontrol agents. Some of them are also important pests of cultivated plants such as soybean, rice and wheat. Altogether 14 species in this family are known to be parasitized by $O$. nutans in Asia and Africa (Table 4). They are Caura pugillator, Erthesina fullo, Halyomorpha halys, H. picus, Homalogonia obtusa, Lelia decempunctata, Nezara antennata, Pentatoma japonica, P. rufipes, Plautia stali and Tropicoris japonicas in subfamily Pentatominae (Esaki 1929, Kobayasi 1949, Moureau 1949, Sasaki et al. 2012), Dinorhynchus dybowskyi and Picromerus lewisi in subfamily Asopinae (Esaki 1929, Yahagi 2008), and Gonopsis affinis in subfamily Phyllocephalinae (Esaki 1929). Among the parasitized bugs, only Caura pugillator is recorded in Africa (Moureau 1949), the rest in Asia. Koval (1974) also recorded O. nutans on Pentatoma sp. in Russia. Two more Ophiocordyceps species parasitize this family. They are $O$. pentatomae parasitizing Pentatoma semiannulata in Russia (Koval 1964) and Lelia decempunctata in Asia (Kobayasi \& Shimizu 1978), and $O$. sichuanensis parasitizing a pentatomid bug in Asia (Liang et al. 2003) (Table 4).

\section{Family Plataspididae}

Most species are distributed in the tropics, mainly in the Orient. They feed on soybean, kidney bean, other legume crops, sugarcane, sweet potato and rice. Coptosoma punctissimum is parasitized by O. nutans in Asia (Esaki 1929) (Table 4). In Africa, a Coptosoma sp. is found to be parasitized by $O$. nutans (Moureau 1949).

\section{Family Tessaratomidae}

Its members are mainly found in the tropics and resemble stink bugs. A Oncomeris sp. is parasitized by $O$. nutans in New Guinea (Kobayasi \& Shimizu 1976) (Table 4).

\section{Family Urostylididae}

Members of this family attack ornamental trees in the Eastern Palaearctic region. Urostylis annulicornis is parasitized by O. nutans in Asia (Sasaki et al. 2012) (Table 4).

\section{Superfamily Pyrrhocoroidea}

Its members are known as true bugs. Callibaphus longirostris in family Pyrrhocoridae is parasitized by O. nutans in Africa (Samson et al. 1982) (Table 4).

\section{Suborder Sternorrhyncha}

The members of this suborder include aphids, whiteflies and scale insects that are cosmopolitan in distribution. They are sedentary and are firmly attached to the host plants. Cordyceps species parasitize scale insects of two families in superfamily Coccoidea (Table 5).

\section{Family Coccidae}

Its members are known as soft scales, wax scales or tortoise scales. Cordyceps confragosa (Mains 1949) and C. piperis (Bischoff \& White 2004) parasitize this family in South America (Table 5). Similarly, C. yahagiana and O. coccidiicola (on Ceroplastes sp.) are recorded on 
members of this family in Asia (Kobayasi \& Shimizu 1978, 1980) (Table 5). Ophiocordyceps clavulata, on the other hand, parasitizes Eulecanium coryli, Lecanium persicae and Coccus sp. in Europe and North America (Fawcett 1886, Ulvinen 1969) (Table 5).

\section{Family Coelostomidiidae}

A single Cordyceps sp., C. novae-zelandiae, parasitizes Coelostomidia sp. in New Zealand (Dingley 1953) (Table 5).

\section{Discussion and Conclusion}

Altogether 52 Cordyceps species are recorded on hymenopterans. All are recorded on suborder Apocrita except Cordyceps coronilla that is recorded on suborder Symphyta and Ophiocordyceps ditmarii recorded on both suborders (Tables 1, 2). Among them, 40 Cordyceps species are recorded on ants (Formicidae, Apocrita) alone. More than 80 ant species are parasitized by Cordyceps species (Table 2). Vespidae is another family of Hymenoptera, of which nearly 20 species are parasitized by Ophiocordyceps sphecocephala, O. ditmarii and others (Table 1).

Ophiocordyceps unilateralis is the most common species that is recorded on 29 ant species (Table 2). Ophiocordyceps myrmecophila is another species recorded on eleven ant species, followed by $C$. australis on seven ant species (Table 2). Ophiocordyceps sphecocephala is another common species, recorded on 16 species of bees and wasps in four families (Table 1). Similarly, $O$. ditmarii is another wasp fungus recorded on seven species of three wasp families (Table 1). Other filamentous fungi and yeasts are also rich in guts of honey bees (Moubasher et al. 2017).

Altogether 44 Cordyceps species are known to parasitize hemipterans. Among them, 34 Cordyceps species parasitize Auchenorrhyncha, six species parasitize Sternorrhyncha and four species parasitize Heteroptera. In suborder Heteroptera, nine families are parasitized by Cordyceps species (Table 4). Similarly, five families in suborder Auchenorrhyncha and at least two families in suborder Sternorrhyncha are parasitized by Cordyceps species (Tables 3, 5). Among all families in Hemiptera, Cicadidae is most commonly parasitized. Nearly 30 cicada species are parasitized by Cordyceps species (Table 3). Some of the commonly parasitized cicada species are Tanna japonensis, Graptopsaltria nigrofuscata, Oncotympana maculaticollis, Platypleura kaempferi and Tibicen bihamatus (Table 3). Pentatomidae is another family, of which 16 species are parasitized by $O$. nutans, including two other species (Table 4). Acanthosomatidae, Coreidae and Aphrophoridae are other commonly parasitized hemipteran families (Tables 3, 4).

Among Cordyceps species parasitizing hemipterans, $O$. nutans parasitizes 33 species in nine families in Asia, Africa and South America (Table 4). Phylogenetically distinct types have been shown for Asian $O$. nutans (Sasaki et al. 2012) that could possibly define $O$. nutans as a species complex in the global scale. Ophiocordyceps clavulata, O. heteropoda, O. sobolifera and $O$. tricentri are few other species parasitizing multiple species of Hemiptera (Tables 3, 5).

All scale insects are parasitized at adult stage (Table 5). Similarly, all host species in Aphrophoridae, Cercopidae, Flatidae and Fulgoridae are parasitized at adult stages (Table 3). Bugs are also mostly parasitized at adult stages (Table 4). However, nymph is the most common stage in cicada family, 25 out of 30 Cordyceps species parasitizing nymphs (Table 3).

In general, Asia, Africa and South America are common continents for Cordyceps species parasitizing hymenopterans, with rare reports from Europe and North America (Tables 1, 2). Similarly, most of Cordyceps species parasitizing hemipterans are recorded in Asia followed by Africa and South America (Tables 3-5). New Guinea, North America, Europe, New Zealand and Russia are rarely described for Cordyceps species on hemipterans.

Insects spend their lives in both agricultural lands and forests depending on season and life stages. Generally, insects spend their lives in forests for purposes such as reproduction, shelter etc. Forests provide optimum conditions for entomopathogenic fungi to parasitize insects by which they can overcome unfavorable environmental conditions by growing inside the body of the insect cadavers. The fungi sprout out of the cadavers when optimum environmental conditions prevail the following year and release spores from summer to early autumn. Spores of entomopathogenic fungi 
on coming in contact with host surface germinate and produce germ-tubes that penetrate the hosts through the cuticular layer with the help of different enzymes such as proteases and chitinases but do not consume the exoskeleton. The cadavers remain intact with the internal organs being replaced by white compact fungal tissue (endosclerotium) of parasitizing Cordyceps species.

Cordyceps species have annual life cycles from the time of infection to its hosts till the fructification the following year. But, it remains curious how Cordyceps species that infect deeply earthed cicada nymphs as long as $50 \mathrm{~cm}$ deep manage to make a way out through the hard layers of soils the following year, leading to their fructification. In any case, the growth rate of Cordyceps species is presumed to be slow in nature. This is also observed in in vitro condition. Localized distributions of most of Cordyceps species could be a bottleneck for its use as wide biocontrol agents; however, there is a possibility of host-targeted propagule production to control agricultural pests. Since many hymenopterans and hemipterans are important agricultural pests, we believe this compiling work will regenerate interest among entomologists, biocontrol experts and specialists, and researchers for the application of insect fungi in conservation agriculture. Besides that, Cordyceps species are also valued for active metabolites that have a broad spectrum of biological activity (Wen et al. 2017).

\section{Acknowledgements}

This work was supported by Korea National Arboretum (Project no. KNA 1-1-10) and the Convergence of Conventional Medicine and Traditional Korean Medicine R\&D project funded by the Ministry of Health \& Welfare through the Korea Health Industry Development Institute (HI15C0094). This work was also supported by the Bio-industry Technology Development Program (316025-05) of IPET (Korea Institute of Planning and Evaluation for Technology in Food, Agriculture, Forestry and Fisheries) of Ministry for Food, Agriculture, Forestry and Fisheries, Republic of Korea. The authors also thank Dr. K.D. Hyde for reviewing and improving the manuscript.

\section{References}

Araújo JPM, Evans HC, Geiser DM, Mackay WP et al. 2015 - Unravelling the diversity behind the Ophiocordyceps unilateralis (Ophiocordycipitaceae) complex: Three new species of zombieant fungi from the Brazilian Amazon. Phytotaxa 220, 224-238.

Araújo JPM, Hughes DP. 2016 - Diversity of entomopathogenic fungi: Which groups conquered the insect body? Advances in Genetics 94, 1-39.

Ban S, Azuma Y, Sato H, Suzuki K et al. 2015 - Isaria takamizusanensis is the anamorph of Cordyceps ryogamimontana, warranting a new combination, Purpureocillium takamizusanense comb. nov. International Journal of Systematic and Evolutionary Microbiology 65, 2459-2465.

Bequaert JC. 1922 - Ants in their diverse relations to the plant world. Bulletin of the American Museum of Natural History 45, 333-583.

Bischoff JF, White JF Jr. 2004 - Torrubiella piperis sp. nov. (Clavicipitaceae, Hypocreales), a new teleomorph of the Lecanicillium complex. Studies in Mycology 50, 89-94.

Cejp K. 1956 - Hynutí vos housenicí Ditmarovou (Cordyceps ditmari Quél.). Czech Mycology 10, 31-36.

Cesati de V. 1879 - Mycetum in itinere Borneensi lectorum a Cl. Od. Beccari lectorum enumeratio. Atti della Real Accademia delle Scienze Fisiche e Matematiche, Napoli, Ser. 1 8, 1-28.

Chen ZC. 1978 - Notes on new Formosan forest fungi VI. Genus Cordyceps and their distribution in Taiwan. Taiwania 23, 153-162.

de Saussure H. 1853 - Monographie des Guêpes Sociales, ou de la Tribu des Vespiens. V. Masson and Geneva, J. Kessmann, Paris.

Dingley JM. 1953 - The Hypocreales of New Zealand V. The genera Cordyceps and Torrubiella. Transactions of the Royal Society of New Zealand 81, 329-343. 
Esaki T. 1929 - On Cordyceps nutans Patouillard from the province of Chikugo. Bulteno Scienca de la Fakultato Terkultura, Kyûsyû Imperia Universitato 3, 221-231.

Evans HC. 1974 - Natural control of arthropods, with special reference to ants (Formicidae), by fungi in the tropical high forest of Ghana. Journal of Applied Ecology 11, 37-49.

Evans HC. 1982 - Entomogenous fungi in tropical forest ecosystems: an appraisal. Ecological Entomology 7, 47-60.

Evans HC. 2001 Entomopathogenic fungi associated with ants (Formicidae): A review. In: Misra JK, Horn BW, ed. Trichomycetes and other fungal groups. Science Publishers, New Hampshire. p. 119-144.

Evans HC, Elliot SL, Hughes DP. 2011 - Hidden diversity behind the zombie-ant fungus Ophiocordyceps unilateralis: Four new species described from carpenter ants in Minas Gerais, Brazil. PloS ONE 6, e1702.

Evans HC, Samson RA. 1982 - Cordyceps species and their anamorphs pathogenic on ants (Formicidae) in tropical forest ecosystems I. The Cephalotes (Myrmicinae) complex. Transactions of the British Mycological Society 79, 431-453.

Evans HC, Samson RA. 1984 - Cordyceps species and their anamorphs pathogenic on ants (Formicidae) in tropical forest ecosystems II. The Camponotus (Formicinae) complex. Transactions of the British Mycological Society 82, 127-150.

Fawcett W. 1886 - An entomogenous fungus. Annals and Magazine of Natural History 18, 316318.

Hennings PC. 1902a - Fungi blumenavienses II. a cl. Alfr. Möller lecti. Hedwigia 41, 1-33.

Hennings PC. 1902b - Einige neue Cordiceps-arten aus Surinam. Hedwigia 41, 167-169.

Hennings PC. 1904 - Fungi Amazonici II. a cl. Ernesto Ule collecti. Hedwigia 43, 242-273.

Hywel-Jones NL. 1996 - Cordyceps myrmecophila-like fungi infecting ants in the leaf litter of tropical forest in Thailand. Mycological Research 100, 613-619.

Johnston JR. 1918 - Algunos hongos entomogenos de Cuba. Memorias de la Sociedad Cubana de Historia Natural 'Felipe Poey' 3, 61-82.

Kaitsu Y, Shimizu K, Tanaka E, Shimano S et al. 2013 - Ophiocordyceps sessilis sp. nov., a new species of Ophiocordyceps on Camponotus ants in Japan. Mycological Progress 12, 755761.

Kautman V, Kautmanová I. 2009 - Cordyceps s.l. (Ascomycetes, Clavicipitaceae) in Slovakia. Catathelasma 11, 5-48.

Kawamura S. 1955 - Icones of Japanese fungi 8. Kazama Shobó Co., Tokyo.

Kepler RM, Ban S, Nakagiri A, Bischoff J et al. 2013 - The phylogenetic placement of hypocrealean insect pathogens in the genus Polycephalomyces: An application of One Fungus One Name. Fungal Biology 117, 611-622.

Kepler RM, Humber RA, Bischoff JF, Rehner SA. 2014 - Clarification of generic and species boundaries for Metarhizium and related fungi through multigene phylogenetics. Mycologia 106, 811-829.

Kepler RM, Kaitsu Y, Tanaka E, Shimano S et al. 2011 - Ophiocordyceps pulvinata sp. nov., a pathogen of ants with a reduced stroma. Mycoscience 52, 39-47.

Kinjo N, Uchiyama S, Kaitsu Y, Tokoo K et al. 2004 - Studies on Cordyceps sobolifera (Hill.) Berk. et Br. (I). Bulletin of College of Liberal Arts and Sciences, Tokyo Medical and Dental University 34, 63-68.

Kobayasi Y. 1939a - On the genus Cordyceps and its allies on Cicadidae from Japan. Bulletin of the Biogeographical Society of Japan 9, 145-176.

Kobayasi Y. 1939b - On the genus Cordyceps and its allies parasitic to Hymenoptera in Japan. Bulletin of the Biogeographical Society of Japan 9, 271-290.

Kobayasi Y. 1941 - The genus Cordyceps and its allies. Science Reports of the Tokyo Bunrika Daigaku Section B 5, 53-260.

Kobayasi Y. 1949 - Several species of the genus Cordyceps and their conidial forms. Journal of Japanese Botany 24, 176-180. 
Kobayasi Y. 1981 - Revision of the genus Cordyceps and its allies 2. Bulletin of the National Science Museum, Tokyo, Series B, Botany 7, 123-129.

Kobayasi Y, Shimizu D. 1963 - Monographic studies of Cordyceps 2. Group parasitic on Cicadidae. Bulletin of the National Science Museum, Series B 6, 286-314.

Kobayasi Y, Shimizu D. 1976 - The genus Cordyceps and its allies from New Guinea. Bulletin of the National Science Museum, Tokyo, Series B, Botany 2, 133-152.

Kobayasi Y, Shimizu D. 1978 - Cordyceps species from Japan. Bulletin of the National Science Museum, Tokyo, Series B, Botany 4, 43-63.

Kobayasi Y, Shimizu D. 1980 - Cordyceps species from Japan 2. Bulletin of the National Science Museum, Tokyo, Series B, Botany 6, 77-96.

Kobayasi Y, Shimizu D. 1982a - Cordyceps species from Japan 4. Bulletin of the National Science Museum, Tokyo, Series B, Botany 8, 79-91.

Kobayasi Y, Shimizu D. 1982b-Cordyceps species from Japan 5. Bulletin of the National Science Museum, Tokyo, Series B, Botany 8, 111-123.

Kobayasi Y, Shimizu D. 1983 - Cordyceps species from Japan 6. Bulletin of the National Science Museum, Tokyo, Series B, Botany 9, 1-21.

Kobmoo N, Mongkolsamrit S, Tasanathai K, Thanakitpipattana D et al. 2012 - Molecular phylogenies reveal host-specific divergence of Ophiocordyceps unilateralis sensu lato following its host ants. Molecular Ecology 21, 3022-3031.

Kobmoo N, Mongkolsamrit S, Wutikhun T, Tasanathai K et al. 2015 - New species of Ophiocordyceps unilateralis, an ubiquitous pathogen of ants from Thailand. Fungal Biology $119,44-52$.

Koval EZ. 1961- Novye vidy Cordyceps iuga primordia. Botaniceskie Materialy Otdela Sporovyh Rastenij Botanicheskogo Instituta Imeni V. L. Komarova, Akademii Nauk SSSR 14, 158-164.

Koval EZ. 1964 - Cordyceps pentatomi Koval sp. nova. Novosti Sistematiki Nizshikh Rastenii 1, 166-168.

Koval EZ. 1974 - Opredelitel Entomofilnych Gribov CCCP. Science Academy of Ukraine, Kiev.

Li CR, Chen MJ, Wang M, Lin YR et al. 2006 - Hirsutella heteropoda sp. nov. and its teleomorph, a new variety of Cordyceps heteropoda. Mycosystema 25, 163-168.

Li CR, Fan MZ, Huang B, Wang SB et al. 2002 - The genus Cordyceps and its allies from Anhui I. Mycosystema 21, 167-171.

Li CR, Huang B, Fan MZ, Lin YR et al. 2010 - Metacordyceps guniujiangensis and its Metarhizium anamorph: A new pathogen on cicada nymphs. Mycotaxon 111, 221-231.

Liang ZQ, Liu AY, Huang JZ. 2002 - Some entomogenous fungi from Wuyishan and Zhangjiajie Natural Reserves I. Cordyceps spp. Mycosystema 21, 162-166.

Liang ZQ, Wang B, Kang JC. 2003 - Several rare entomopathogenic fungi from Western Sichuan Mountains. Fungal Diversity 12, 129-134.

Luangsa-Ard JJ, Ridkaew R, Tasanathai K, Thanakitpipattana D et al. 2011 - Ophiocordyceps halabalaensis: a new species of Ophiocordyceps pathogenic to Camponotus gigas in Hala Bala Wildlife Sanctuary, Southern Thailand. Fungal Biology 115, 608-614.

Mains EB. 1939 - Cordyceps from the mountains of North Carolina and Tennessee. Journal of the Elisha Mitchell Scientific Society 55, 117-129.

Mains EB. 1940 - Species of Cordyceps. Mycologia 32, 310-320.

Mains EB. 1949 - New species of Torrubiella, Hirsutella and Gibellula. Mycologia 41, 303-310.

Mornand J, Girod G, Péan R. 2012 - Les Cordyceps entomophiles en Europe, http://www.ascofrance.com/uploads/document/Catalogue-des-Cordyceps1-0001.pdf

Moubasher AH, Abdel-Sater MA, Zeinab S. 2017 - Yeasts and filamentous fungi inhabiting guts of three insect species in Assiut, Egypt. Mycosphere 8, 1297-1316.

Moureau J. 1949 - Cordyceps du Congo Belge. Mémoires de l'Institut Royal Colonial Belge 7, 158.

Moureau J. 1961 - Nouveaux Cordyceps du Congo. Lejeunia Mémoires 15, 1-38. 
Nylander W. 1869 - Observationes circa Pezizas Fenniae. Notiser ur Sällskapets pro Fauna et Flora Fennica förhandlingar 10,1-98.

Penzig O, Saccardo PA. 1897 - Diagnoses fungorum novorum in insula Java collectorum. Malpighia 11, 491-530.

Petch T. 1932 - Notes on entomogenous fungi. Transactions of the British Mycological Society 16, 209-245.

Petch T. 1934 - Contributions to the flora of tropical America: XX. Entomogenous fungi from British Guiana. Bulletin of Miscellaneous Information (Royal Botanic Gardens, Kew) 1934, 202-205.

Pontoppidan MB, Himama W, Hywel-Jones NL, Boomsma JJ et al. 2009 - Graveyards on the move: The spatio-temporal distribution of dead Ophiocordyceps-infected ants. PLoS ONE 4, e4835.

Quandt CA, Kepler RM, Gams W, Araújo JPM et al. 2014 - Phylogenetic-based nomenclatural proposals for Ophiocordycipitaceae (Hypocreales) with new combinations in Tolypocladium. IMA Fungus 5, 121-134.

Saccardo PA. 1883 - Sylloge Fungorum Vol 2, Pyrenomycologiae Universae, Padua.

Saccardo PA. 1891 - Sylloge Fungorum Vol 9, Supplementum Universale, Padua.

Saccardo PA. 1895 - Sylloge Fungorum Vol 11, Supplementum Universale, Padua.

Saccardo PA. 1905 - Sylloge Fungorum Vol 17, Supplementum Universale, Padua.

Saccardo PA, Trotter A. 1913 - Sylloge Fungorum Vol 22, Supplementum Universale, Padua.

Samson RA, Evans HC, Hoekstra ES. 1982 - Notes on entomogenous fungi from Ghana. VI. The genus Cordyceps. Proceedings of the Koninklijke Nederlandse Akademie van Wetenschappen, Series C, Biological and Medical Sciences 85, 589-605.

Sanjuán T, Henao LG, Amat G. 2001 - Distribución espacial de Cordyceps spp. (Ascomycotina: Clavicipitaceae) y su impacto sobre las hormigas en selvas del piedemonte amazónico de Colombia. Revista de Biología Tropical 49, 945-955.

Sanjuán TI, Franco-Molano AE, Kepler RM, Spatafora JW et al. 2015 - Five new species of entomopathogenic fungi from the Amazon and evolution of neotropical Ophiocordyceps. Fungal Biology 119, 901-916.

Sasaki F, Miyamoto T, Yamamoto A, Tamai Y et al. 2012 - Relationship between intraspecific variations and host insects of Ophiocordyceps nutans collected in Japan. Mycoscience 53, $85-91$.

Shing S. 1975 - Classification of Cordyceps sobolifera (Hill) Berk. et Br. and Cordyceps cicadae Shing sp. nov. Acta Microbiologica Sinica 15, 21-26.

Shrestha B, Tanaka E, Han JG, Oh J et al. 2014 - A brief chronicle of the genus Cordyceps Fr., the oldest valid genus in Cordycipitaceae (Hypocreales, Ascomycota). Mycobiology 42, 93-99.

Shrestha B, Tanaka E, Hyun MW, Han JG et al. 2016 - Coleopteran and lepidopteran hosts of the entomopathogenic genus Cordyceps sensu lato. Journal of Mycology 2016, article ID 7648219.

Shrestha B, Zhang WM, Zhang YJ, Liu XZ. 2010 - What is the Chinese caterpillar fungus Ophiocordyceps sinensis (Ophiocordycipitaceae)? Mycology 1, 228-236.

Sobczak JF, Costa LFA, Carvalho JLVR, Salgado-Neto G et al. 2017 - The zombie ants parasitized by the fungi Ophiocordyceps camponoti-atricipis (Hypocreales: Ophiocordycipitaceae): new occurrence and natural history. Mycosphere 8, 1261-1266.

Spatafora JW, Quandt CA, Kepler RM, Sung GH et al. 2015 - New 1F1N species combinations in Ophiocordycipitaceae (Hypocreales). IMA Fungus 6, 357-362.

Spegazzini CL. 1881 - Fungi Argentini. Anales de la Sociedad Científica Argentina 12, 208-227.

Spegazzini CL. 1889 - Fungi Puiggariani. Pugillus 1. Boletin de la Academia Nacional de Ciencias en Córdoba (República Argentina) 11, 381-625.

Sung GH, Hywel-Jones NL, Sung JM, Luangsa-ard JJ et al. 2007 -Phylogenetic classification of Cordyceps and the clavicipitaceous fungi. Studies in Mycology 57, 5-59. 
Tasanathai K, Thanakitpipattana D, Noisripoom W, Khonsanit A et al. 2016 -Two new Cordyceps species from a community forest in Thailand. Mycological Progress 15, 28.

Teng SC. 1934 - Notes on Hypocreales from China. Sinensia 4, 269-298.

Teng SC. 1935 - Supplementary notes on ascomycetes from China. Sinensia 6, 185-217.

Tulasne LR, Tulasne C. 1865 - Selecta Fungorum Carpologia III. Imperatoris Jussu, Paris.

Tzean SS, Hsieh LS, Wu WJ. 1997 - Atlas of entomopathogenic fungi from Taiwan. Council of Agriculture, Taiwan, R.O.C.

Uchiyama S, Udagawa S. 2002 - Cordyceps owariensis f. viridescens and its new Nomuraea anamorph. Mycoscience 43, 135-141.

Ulvinen T. 1969 - Hyönteisissä elävistä Cordyceps-lajeista eräistä kuroma-asteisista sienistä. Pikkutietoja - Notulae. Annales Entomologici Fennici 35, 234-237.

van Vooren N, Audibert C. 2005 - Révision du complexe «Cordyceps sphecocephala » $1^{\mathrm{re}}$ partie : les guêpes végétales. Bulletin mensuel de la Société linnéenne de Lyon 74, 221-254.

Wen TC, Long FY, Kang C, Wang F et al. 2017- Effects of additives and bioreactors on cordycepin production from Cordyceps militaris in liquid static culture. Mycosphere 8, 886898.

Wolcott GN. 1948 - The insects of Puerto Rico. Hymenoptera. The Journal of Agriculture of the University of Puerto Rico 32, 749-975.

Yahagi N. 2008 - Illustrated catalogue of Japanese Cordyceps (entomonogenous fungi): The Yahagi collection of Japanese Cordyceps stored in the Tohoku University Museum. Bulletin of the Tohoku University Museum 8, 29-89. 